\title{
Assessment of Educational Planning and Policy Implementation
}

\author{
Mba, Callistus Okechukwu Ph.D ${ }^{1}$, Ugwulashi, Chima Sebastine Ph.D ${ }^{2 *}$ \\ ${ }^{1}$ Department of Educational Management, Faculty of Education, University of Port Harcourt, Port Harcourt, \\ Nigeria. \\ ${ }^{2}$ Health, Safety and Environment @ Eni Group Port Harcourt, Nigeria.
}

*Corresponding Author: Ugwulashi, Chima Sebastine Ph.D, Health, Safety and Environment @ Eni Group Port Harcourt, Nigeria.

\begin{abstract}
Education is regarded as the key to the development of any nation - a key to a country's political, economic, social and technological development. The importance of education cannot be overemphasized because it opens doors for development, modernization, civilization and industrialization to any nation. On the issue of planning, it is a deliberate effort to determine the future course of action for accomplishing predetermined goals and objectives. There are different importance of Educational planning which some of them are (1) helps in aiding decision making in education and (2) helps in identifying educational goals and objectives on policy implementation. it has some problems associated to it which some of them are (1) overestimation of available resources and (2) under-estimation of available resources. Some Nigerian factors also militate against the implementation of Educational policies which include (1) lack of political will and (2) corruption. Implementation of educational policy is very important because it helps for its actualization. Some recommendations were made (1) there should be enough funds for the education industry and (2) government should as a matter of necessity eradicate corruption at all levels especially in the education sector for the betterment of our future generation.
\end{abstract}

Keywords: Education, Educational Planning, Policy Implementation

\section{INTRODUCTION}

All over the world, education is regarded as the key to the development of any nation. It is the tool for a country's political, economic, social and technological development. For education to play its key role in the transformation of a nation, it needs to be adequately and effectively planned because a faulty educational planning can jeopardize the development of a nation for decades. Planning means deciding in advance what is to be done, when to do it, where to do it, how to do it and who is to do it in order to achieve predetermined goals and objectives. Educational planning on the other hand, involves a systematic and scientific set of decisions for future action with the aim of achieving set out educational goals and objectives through optimal use of scarce resources. This implies that educational planning provides the tool for coordinating and controlling the direction of the different components of an educational enterprise so that educational objectives can be achieved.

Prior to 1977 Nigeria operated an educational policy inherited from Britain at independence. The inability of this policy to satisfy the national aspirations of the country rendered it unpopular. In 1969 a National Curriculum Conference was organised which reviewed the inherited curriculum and identified new national goals for Nigeria's education. A National Seminar was organised by the National Educational Research and Development Council (NERDC) in 1973 under the Chairmanship of Chief S. O. Adebo. This gave rise to the National Policy on Education in 1977 (Akangbou 1985; Bello 1986; Okoroma 2000). The National Policy on Education is anchored on Nigeria's philosophy on education as enunciated through the nation's objectives. Nigeria has five main national objectives as provided by the Second National Development Plan and accepted as the necessary foundation for the National Policy on Education. They are the building of:

- a free and democratic society

- a just and egalitarian society

- a united strong and self-reliant nation

International Journal of Humanities Social Sciences and Education (IJHSSE) 
- a great and dynamic economy

- $\quad$ a land of bright and full opportunities for all citizens (FRN, 2014).

In any country, educational planning according to Akpan (2011) is necessitated by varied reasons which include among others, the desire of government to meet the yearnings, needs and aspirations of the citizenry, the demand for education and access to education, provide quality education to the people, to respond to technological development, to ensure global competitiveness and more importantly to actualize government political philosophy. However, the type of educational planning adopted in a country is not decided by professional planners, technical planners and or the democrats but by the polity. The polity is a representative body of the government in power at the time of the educational planning. Thus, the government is responsible for identifying the overall goal of education and also gives the directives of the plan. The polity or legislature representing the government decides on the time frame as well as takes the final decision on the form of the plan. There are various types of educational planning. The government may decide to adopt short-term, long-term or strategic educational planning provided the type chosen will help the government to actualize its political agenda or ideology. Therefore, the importance of educational planning for the achievement of educational goals cannot be overemphasized.

Thus, this chapter is discussed under the following subheadings:

1. Concept of education

2. Importance of education

3. Concept of planning

4. Concept of Educational planning

5. Concept of Importance of educational planning

6. Concept of Reasons for planning education

7. Concept of Policy as a concept

\section{CONCEPT OF EDUCATION}

The literature on the concept of education reveals that the word "education" is derived from three Latin words namely:

- Educatum - the act of teaching or training of an individual or group of individuals.

- Educare - to bring up or to raise.

- Educere - to lead forth or to come out (Wikipedia, n.d).

All these three meanings depict that education involves the process of training a person to develop in $\mathrm{him} / \mathrm{her}$ the good qualities and bring out the best in the person. It is the act of training or teaching an individual to learn and acquire desirable skills, attitude, knowledge, values and understanding that will enable the person to think critically about the various issues in life. Education involves the process of teaching and learning. The learner is taught to understand the deeper things of life, the need for good human relation and the cause and effect relationship in life. Education can also be viewed as any act or experience that has a formative effect on the mind, character or physical ability of an individual. It is the process by which a society deliberately transmits its accumulated knowledge, skills and values from one generation to another.

These definitions reveal that education is not only limited to formal education but also involves informal and adult education. Education is an enlightening experience that illuminates the mind and enables the individual to make informed decisions about himself or herself and to constructively contribute to the development of the society. Therefore, it is the process of training an individual to develop his intellectual and mental potentials so that the person can make mature and useful decisions in various situations. According to Froebel cited in Peerzada (2016), education is the unfolding of what is already enfolded in the man. This implies that education is a process through which a person is trained to develop his innate potentials so that it can be fully expressed externally. This means that education is the gradual or progressive development of a person's innate powers or potentials. It is development from within the individual until the person becomes conscious of his unique existence and begins to seek his own place in the society (Peerzada, 2016). Education deals with the 
development of the total man or the whole man. This means that education is an act that trains man in the cognitive (knowledge), affective (feelings, attitude, behaviour) and psychomotor domains. Education involves all-round development of the person. It therefore, develops an individual into a well educated, cultured, disciplined, employable and productive person. Education leads, guides and directs the learner to the acquisition of desirable knowledge, attitude, and healthy behaviour (Akpan, 2000). In this period of continuous technological development and globalization, education should train man to acquire knowledge and skills that will enable the person to compete favourably globally and to successfully adjust to changes in the environment.

\section{IMPORTANCE OF EDUCATION}

Education is the key that opens the doors for development, modernization, civilization and industrialization of any nation. It is the means, through which a nation can harness its numerous resources, develop manpower and improve the quality of the life of the citizens. In any country of the world, education is the backbone of scientific and technological development. It enhances selfreliance for an individual and the nation. A nation that is self-reliant does not depend on foreign goods/services for survival and self-reliant people do not depend on government for the provision of employment. The individual can gainfully employ himself/herself and be able to attend to his/her critical needs. In this way education reduces the level of poverty in a nation. Thus, quality functional education contributes to national development in this direction. Education liberates the people from ignorance, promotes socio-economic and political development of a nation. It is on the basis of this that Nigeria adopts education as an instrument par-excellence for national development (FRN, 2014).

Education is very vital in every human existence and societal development. It facilitates the rate of development and improves the standard of living of the people. A well educated person acquires knowledge for critical thinking and can use the knowledge and skills acquired through education to create wealth especially now that we are living in a knowledge driven-economy. Education helps a person to understand the society better and contribute positively to its development and become more useful to the society. It is through education that the task of processing human resources into well trained human capital needed in any country of the world can be achieved. Thus, education is an investment in human capital development.

Omolewa (2006) reiterates that the greatest investment a country can make especially for national development is the commitment to the training of its citizens in form of education. This implies that education is the bedrock of a country's growth and progress and a veritable instrument to bring about the desired economic transformation. Education helps the citizens of a country to understand the cultures of various tribes or ethnic groups within the same country. This understanding enhances peaceful co-existence and promotes in them the knowledge of national integration. Education contributes immensely to designing the social structure of a society.

Education is the sure way to sustainable development of a country's economy. The world of today is technology- driven especially information communication technology (ICT). Therefore, education in this area is important for the future economic development of developing nations. Similarly, education is a promoter of national interest. A good educational system produces people with critical intelligence and wisdom. These people can work independently and come out with independent results and conclusions from given facts. Such conclusions stand to benefit the nation and the people. Education helps to produce global citizenship that works for the benefit of humanity. Such educated people exhibit humility, have moral integrity and are wise and tolerant. They work for the common good of man. Thus, the development of all aspect of national economy depends on the manpower development through education. It is on the basis of this that educational planning becomes imperative.

\section{Concept of Planning}

Planning is fundamental to the achievement of set out goals. Planning is a deliberate effort to determine the future course of action for accomplishing predetermined goals and objectives. Akpan (2011) conceptualizes planning as the process of examining the future and drawing up or mapping out a course of action for achieving specified goals and objectives. It involves working out in broad outline the things to be done and procedures for doing them in order to accomplish set purpose. It is a process of making rational and technical choice. Planning is a systematic, conscious and deliberate process of deciding ahead of time, the future course of action that 
a person wishes to pursue in order to reach set goals. This definition suggests that planning is part and parcel of every man's endavour politically, socially, economically and academically.

Similarly, UNESCO (2003) describes planning as a process that makes it possible to work out a systematic outline of activities to be undertaken in order to meet the developmental objectives of a country within that country's possibilities and aspirations. This definition depicts that planning is both futuristic and goal-oriented. It is intelligent preparation for actions that will lead to the achievement of predetermined goals and objectives (Akpan, 2000). It involves a conscious, careful and systematic process of arranging a future course of action directed at goal accomplishment. Planning therefore, provides the direction in relation to objectives, activities, procedures, strategies, and cost implications, sources of fund, responsibilities and duration or time frame for attainment of set objectives. It spells out what is to be done, who to do it, when it should be done and how it should be done in order to reach set target.

Planning is a careful analysis of relevant information from the present and the past and using such information to predict future development so that a course of action can be determined that may enable attainment of stated objectives. Planning is concerned with the future and involves predicting the effect of future events so that hindrance of the presence could be minimized or eliminated in order to meet the future with more confidence and success. Therefore, planning gives direction; enhances continuity of actions and reduces overlapping of responsibilities, waste of time, energy and resources (Akpan, 2000).

\section{Concept of Educational Planning}

Educational planning involves a systematic and scientific set of decisions for future action with the aim of achieving set out educational goals and objectives through effective use of scarce resources. It provides the tool for coordinating and controlling the direction of the educational system so that educational objectives can be realized. It is a process of identifying and classifying educational needs of a nation and the direction education should take and the strategies for implementing decisions concerning educational development. Akpan (2000) maintains that educational planning should reflect the state of development of a nation including the needs and readiness to execute the planned objectives. Thus, educational planning must take into consideration the population growth of children of school age in relation to access to education, educational opportunities and the demand for education.

Comb cited in (Akpan, 2000) describes educational planning as the application of rational systematic analysis to the process of educational development with the aim of making education more effective and efficient in responding to the needs and goals of the learners and the society. This means that educational planning should take into account the needs of the pupils/students in terms of learning facilities and equipment, textbooks, classroom spaces and qualified educational personnel. In meeting the needs of the society, educational planning should take cognizance of the manpower, cultural, social and communication needs of the society (nation) as well as the economic changes (Akpan, 2000). Therefore, educational planning is a blue-print that gives direction for future development of a nation's educational system and prescribes courses of actions for achieving defined goals and objectives. Educational planning involves restructuring of the present educational system, forecasting future possibilities, formulating realistic and achievable goals and objectives developing action plans for implementation and periodic appraisal of progress and achievement. The political, social, economic and technological needs of a nation must be considered in educational planning.

In support of this fact, Beeby cited in Okwori (2011) states that educational planning is the exercise of foresight in determining the policy, priorities and cost of educational system having due regards for economic and political realities for the system potentials, for growth and for the needs of the country and of the pupils served by the system. This implies that educational planning is a scientific study of the future with regard to a nation's educational development. The future development of a nation is the focus of educational planning. It involves studying the future educational needs of a country and putting in place relevant policies and priorities, actions, and programmes that will enhance achievement of set out educational goals. Educational planning does not just happen by chance. It is an organized social practice involving studying the present and using available information concerning the educational challenges of a country to plan for future educational needs and development. The outcome of educational planning is the education plan which contains educational 
policies, goals and objectives, activities and programmes to be carried out, implementation strategies, method of monitoring and evaluation of achievement and progress and the time frame for implementation.

\section{Importance of Educational PlanNing}

* It helps in identifying educational goals and objectives.

* It helps in even or effective distribution of scarce resources.

* It aids decision making in educational system

* It is necessary for administrative decision making in school.

* It enables a nation to make her choices clear in terms of educational needs.

* It enhances optional utilization of resources and so eliminates imbalance and waste.

* Effective planning makes provision for quality education, sustainable national economy.

* Effective educational planning enhances investment in human capital which leads to rapid national economic growth.

* Educational planning reduces exigencies in the educational sector. Problems are anticipated in time and dealt with appropriately.

* It enables stakeholders in education to gain economic insight in the use of scarce educational resources. Since education is a social good that provides benefits to the people and the nation, it is important that education should be well planned.

* Well planned education enhances literacy and reduces ignorance among citizens.

* Planning gives direction and guidelines for a country's educational system.

\section{REASONS FOR PLANNING EDUCATION}

A plethora of environmental and situational variables impact greatly on our educational system; the effect of these variables make educational planning imperative. These factors include but not limited to:

1. The increasing cost of education in Nigeria.

2. The impact of technological development all over the world.

3. The impact of globalization on national development.

4. Unemployment.

5. Social changes.

6. Global citizenship and competitiveness.

7. Inflationary trend.

8. Poverty.

9. Increasing demand for and access to education.

10. The growing need for professionalization of the education enterprise.

Effective and proper educational planning is necessary in order to minimize or completely eliminate the effect of these factors on educational system. Akpan (2000) points out that our country is plagued with a lot of uncertainties. These include economic and political uncertainties. These problems abound both within and outside the educational system. The purpose of educational planning is to deal realistically with these uncertainties. Mark cited in Akpan (2000) states that dealing sensibly with uncertainty is not a byway on the road to responsible business and government decisions. Thus, with effective forecasting or planning our educational system can be made less uncertain (Akpan, 2000).

We live and operate in a dynamic and changing society, so are our educational institutions. In some cases, these changes may be rapid or gradual. In whatever rate the changes occur, the educational enterprise is affected directly or indirectly. Thus, for the educational system to remain in a state of 
equilibrium in an ever-changing society like ours there is need for educational planning in order to forecast the future and plan for it. Our educational system is faced with scarce human and materials resources. Optimal utilization of these scarce resources calls for effective planning. Proper planning saves time, energy and resources and enhances successful implementation of education plan and attainment of educational goals and objectives. It brings about effectiveness in the execution of educational activities, actions and programmes as well as promotes high productivity of educational personnel. According to Ukeje in Akpan (2000), careful planning reduces the number of emergencies as these are anticipated in time and taken care of. Good planning therefore, avoid decision random for all decisions are carefully related into a coordinated whole.

Educational planning specifies the goals, values and practices and gives the direction for future educational development of a country. It also specifies and sets a limit to a course of action related to education in a country (Adepoju, 2000). The impact of information and communication technology which has turn the entire world into a global village calls for the restructuring and effective planning of education in order to equip learners with current scientific and technological development all over the world. These will make our graduates to acquire scientific and technological knowledge that can make them to be global citizens that can compete globally. Similarly, the need to tackle the galloping rate of unemployment and poverty in Nigeria calls for effective planning of our educational system. The poverty level is increasing rapidly, so is the rate of unemployment. In order to tackle this menace in our society we need the type of educational system that can equip learners with skills and knowledge that will help them to create jobs for themselves so as to reduce or eliminate poverty. This can only be achieved through careful educational planning.

The high level of inflation and the ever increasing cost of education in Nigeria have led to students' dropout from schools. Many of them do not have access to education especially those from poor socio-economic background. They cannot pay their fees because of high cost of education. Therefore there is need to have a rethinking of our educational system. Hence the need for proper educational planning that can take care of the less privilege and the vulnerable. The desire to develop quality and adequate manpower to man the various sectors of the country's economy necessitates the need for effective educational planning. The desire to attain political, socio-economic and cultural progress of a country calls for educational planning. When there are existing contradictions, ambiguities as well as inequalities in educational practices in a nation, educational planning becomes necessary to address these problems. Educational planning is done to reform the educational system of a country in terms of duration of education cycles, the curriculum, quality of education and system structure. In this way educational planning improves effectiveness, efficiency and productivity.

\section{POLicy as A CONCEPT}

A policy according to Okoroma (2006) serves the purpose of ensuring that every official action of an organisation must have a basis or a backing. Terry (1977) considers that "a policy is an overall guide that gives the general limits and direction in which administrative action will take place". According to him, "a policy defines the area in which decisions are to be made but it does not give the decision". A policy brings about a meaningful relationship between business objectives and organisational functions as it discourages deviations from planned courses of action. A policy ensures consistency of action because an organisation is governed by approved principles. A policy does not have to be rigid, as there should be room for adjustment if necessary after its formulation. Perhaps this is why Hoy and Miskel (2005) believe that "policies are not only formulated but also programmed, communicated, monitored and evaluated"? The non-rigid nature of policies is confirmed by Lindblom (1959) as a "process of successive approximation to some desired objectives in which what is desired itself continues to change under reconsideration". In fact, a good policy is one that can be reviewed as the need may arise. Lindblom believes that a wise policy maker cannot expect all their policies to achieve a one-hundred percent success. Regardless of how good a policy may be, its implementation may introduce some elements of imperfection.

\subsection{The Concept of Educational Policy}

Educational policies are initiatives mostly by governments that determine the direction of an educational system (Okoroma 2000). Education is a distinctive way in which the society inducts its young ones into full membership. So every modern society needs some educational policies to guide it in the process of such initiation. In the view of Awokoya (1981), educational policy is directed 
towards increasing the quality of life of a people. He believes that the objective of any policy is to satisfy individual needs, community pressures and the degree of complexity and sophistication to which socialized personnel must be educated and trained to meet these demands. The following considerations, according to Awokoya (1981), are necessary to guide the formulation of adequate educational policy.

- It should be formulated and adopted through a political process which acknowledges the reality and legitimacy of conflicting interests and desires among its participants

- It should portray some elements of guidance for properly directed and coordinated action towards the attainment of the desired goals

- It should contain information on the broad objectives that should be reached

- It should be a binding guide on the actions of those implementing it

- It should be enforceable and enforced by the society which formulates it.

Kerr (1976) believes that, for a policy to qualify as an educational policy, it must be distinct from other policies. In his view, educational policies are distinguishable from other policies by the fact that policies on education are part and parcel of educational institutions. However, it is important to note that not all policies formulated in educational institutions can qualify as educational policies. Generally, policies must be rational and purposeful to enable them to stand the test of time.

Since policy process is a crucial element in educational planning, it is essential to clarify the concepts of 'policy' and 'policy making' before proceeding any further. Understandably, competing definitions of 'policy' are numerous and varied. For the purposes of this paper, policy is defined functionally to mean: An explicit or implicit single decision or group of decisions which may set out directives for guiding future decisions, initiate or retard action, or guide implementation of previous decisions. Policy making is the first step in any planning cycle and planners must appreciate the dynamics of policy formulation before they can design implementation and evaluation procedures effectively.

Policies, however, differ in terms of their scope, complexity, decision environment, range of choices, and decision criteria. Issue-specific policies are short-term decisions involving day-to-day management or, as the term implies, a particular issue. A programme policy is concerned with the design of a programme in a particular area, while a multi-programme policy decision deals with competing programme areas. Finally, strategic decisions deal with large-scale policies and broad resource allocations. Although decision making is a crucial event in the policy process, clearly it is proceeded by analytical and political activities (analysis, generation of .options, bargaining, etc) and followed by equally important planning activities (implementation, assessment, and possible redesign).

\subsection{Problems Associated with Policy Implementation}

The gap that often exists between policy formulation and implementation provokes inquiry to identify factors that constrained the effective implementation of educational policies. The problem of policy implementation is traceable to the planning stage which comes immediately after policy formulation. Ukeje (1986) stated clearly that good planning will ensure effective implementation. Good planning that can facilitate effective implementation ought to consider such factors as the planning environment, social environment, political environment, and financial and statistical problems. It is in recognition of this observation, that Aghenta (1984) noted: For education to achieve all ends, it has to be carefully planned. The plan must take into consideration ... the needs of the society; the political, socio-cultural, economic, military, scientific, and technological realities of the environment are very important to its survival.

Adesina (1977) notes that planned implementation is constrained by the following factors:

a) over-estimation of available resources - this is a situation where estimated resources are greater than actual available resources to implement a program

b) under-estimation of the costs of implementing a plan - this happens when cost-estimates do not make adequate provisions for inflation and actual implementation costs become unmanageable

c) over-reliance upon external assistance - plans that substantially rely upon assistance from foreign sources for their implementation run into hitches when such aid fails to come, and 
d) inaccurate statistical data - planning education requires accurate and up-to-date data. Plans that do not adequately provide for this usually have implementation problems. Furthermore, Van Horn and Van Meter (1977) also advanced three general explanations for unsuccessful implementation of programs, namely:

e) the communication process - effective implementation requires that implementers know what they are expected to do; as messages pass through any communication network, distortions are likely to occur which can produce contrary directives, ambiguities, inconsistencies and incompatible requirements;

f) the capability problem - ability to implement policies may be hindered by such factors as incompetent staff, insufficient information, political support, inadequate financial resources and impossible time constraints, and

g) dispositional conflicts - implementation of a policy may fail because those charged with the responsibility of implementation refuse to carry out their own assignments.

\subsection{Nigerian Factors that Militate Against the Implementation of Educational Policies}

Efforts have been made to develop education in Nigeria since independence in 1960. Various policies in the interest of education have been formulated. Unfortunately, these efforts have not produced the desired effect. The state of education in Nigeria is still deplorable. It is so bad that some resourceful Nigerians prefer to send their children to Europe, America and even small African countries such as Ghana that has few universities as against over one hundred universities in Nigeria that lack adequate learning facilities. Apart from the general problems of policy implementation common to most countries, especially those of the third world, some factors have been identified as peculiar to Nigeria and inhibiting educational growth. It is no longer news that Nigeria is the giant of Africa in terms of resourcefulness as a major oil and gas producer. Ironically, Nigerians education budget is below acceptable UNESCO standard of $26 \%$. The following reasons, among others, account for the poor implementation of educational policies.

\subsection{Lack of Political Will}

Ordinarily, Nigerian leaders would want the country to stand out best in everything, including education. However, political will has been lacking. Perhaps this is as a result of instability of governments and or lack of continuity. Between 1960 and 2019, the country has had several governments led by Belewa (late), General Aguiyi Ironsi (late), General (Dr.) Yakubu Gowon, General Murtala Mohammed (late), General Olusegun Obansanjo (as Military Head of State), Alhaji Shehu Shagari, General Mohammadu Buhari, General Ibrahim Babangida, Chief Earnest Shonekon, General Sani Abacha (late), General Abdusalam Abubakar, Chief Olusegun Obasanjo, Musa Yara dua, Goodluck Jonathan and Mohammadu Buhari (current president). In forty five years, Nigeria has had twelve heads of state out of which only four were democratically elected. Others came through military intervention. This shows that most Nigerian leaders have never had time to draw-up plans of action before they drafted themselves or were drafted into leadership and therefore have been illprepared for any development efforts whether in education or other spheres. Most of their actions were not patriotic but for personal aggrandizement.

Even Chief Olusegun Obasanjo (Former President) had no program of action before he was drafted to become president in 1999. Chief Obasanjo was jailed for life by the late General Sani Abacha on treasonable charges. The demise of General Abacha installed General Abdusalam Abubakar who released Obasanjo from jail, granted him presidential pardon and supported him to become president. Educational policies were formulated by various governments but political instability stalled or discouraged the political will to implement such policies. As new governments came in quick succession and with relative uncertainty, continuity in policies could not be guaranteed. Every political player was in a hurry to help himself before he was displaced by another group. This has affected educational policy implementation in Nigeria.

\subsection{Corruption}

If anything has contributed greatly to the stagnation of corporate development of Nigeria, it is this virus called 'corruption'. It is found in all aspects of human endeavour in Nigeria. Its prominence in Nigeria has earned our nation a place of negative prominence in the world. Adesina (2004) notes the 2014 Corruption Perceptions Index, released by Transparency International (TI), the watchdog on 
global corruption, ranks Nigeria as the second most corrupt country in the world. In 2003, the organization ranked Nigeria second, a one-step improvement from the previous position as the most corrupt country in the world. Although President Olusegun Obasanjo of Nigeria was uncomfortable and disputed the rating, many Nigerians agreed that it was correct. This is because corruption pervades all segments of Nigeria's national life. Despite enormous oil and gas wealth at the disposal of the country, basic things of life such as food, shelter, portable water, electricity, good roads and education have become luxuries to the citizens. However, people at the various levels of governments and their agents wallow in enormous financial and material wealth. Presently 2018 statistics ranked Nigeria as 144 out of 180 corrupt nations.

Corruption has contributed to stagnate the development of education in Nigeria. Some educational policies have been put in place like the National Policy on Education discussed. The designers of the policy, from all intents and purposes, were quite visionary. Although, the objectives of most policies in Nigeria are often derailed at the implementation stage due to a number of reasons:

(1) The budgets for the implementation of the policies are often passed by lawmakers with strings attached to them;

(2) Even when the budgets are passed, the executive arm of government is often reluctant to release the funds to facilitate implementation, and

(3) The inadequate funds often released to the operators of the education system (primary schools, secondary schools and tertiary institutions) are not honestly and fully utilised to promote the cause of education. Many corruptly divert much of the available education resources to serve personal interests.

Aghenta (1984) supports these observations that the money available is never carefully used. The money the government votes for running the schools ... does not get to the schools and the little that gets there is normally wasted by those whose responsibility it is to manage the schools. Since the reestablishment of democracy in Nigeria in 1999, the state of education has further deteriorated. The UNESCO standard for education for all nations of the world is $26 \%$ of the national budget. During the era of dictatorship (military government) in Nigeria, education received as much as $13 \%$. But the present democratic government in Nigeria has fallen short of this. For example, in 2001, it allocated $8 \%$ to education. In 2004, the Federal Government's provision for education was a dismal $5.6 \%$ of the budget. The issue of corruption in education became more prominent in 2005 when President Olusegun Obasanjo made a broadcast to the nation alleging that some members of the National Assembly demanded and collected N55 million from Professor Fabian Osuji (former Minster of Education). The Senate President and five other senators were involved in the deal. According to President Obasanjo the purpose of the bribe was to enable the National Assembly to approve an enhanced budget for the Ministry of Education (Obasanjo 2005). All the facts available show that the refusal to accede to such a bribery demand meant doom for the education sector for the year. It is rather unfortunate that senators who are senior citizens expectedly demanded an inducement before they would approve that Nigerian children should go to school.

Adighije (2005) confirmed that bribes to the National Assembly is a normal practice and that every Minister does it. Osuji (2005), who was involved in the corruption scandal, admitted having given N55 million to the Senate Committee on Education but said it was a public relations gift and not a bribe. According to him, other Ministers do the same to have their budgets passed in line with their proposals. This implied that such practice must have been going on over the past fifteen years of democracy in Nigeria to the detriment of educational development. No doubt these unfortunate and corrupt practices affect implementation as they occur at the various stages of program execution. Ejiogu (2005) concurs that the cankerworms of corruption and gross mismanagement of resources have been blamed for the deplorable state of the country's educational system. As a result of these two factors, the sector has consistently witnessed scarcity of resources, to the extent that less then 20 percent of eligible children of secondary school age get enrolled into schools. At the tertiary level, only 0.3 percent of Nigerian youths who are due for enrolment at that level get the opportunity to go into higher institutions.

\subsection{Planning Policy Implementation}

Once a policy has been chosen, planning for policy implementation should begin immediately. Although much of the work that must be carried out during this stage can be based on evaluations 
performed to make the policy decision, planning for implementation involves a concreteness absent in earlier stages of the policy process. What was abstract during the evaluation stage begins to become concrete during planning. A schedule for moving people, physical objects and funds must be drawn up with a clarity and attention to detail that leaves no doubt as to who will do what, when and how; physical resources, once the content of hypothetical lists, must be located and their availability assured; financial resources, once ear-marked for possible use, must be appropriated so that implementation delays are minimal; the personnel needed to put plans into action must be freed from other commitments and made ready to go to work; the technical knowledge needed to guide the policy implementation must be mastered by those who will employ it; and the administrative systems within which the policy will be directed must be clearly structured and firmly in place.

Ambitious as these tasks are, there is one planning task that is more difficult (and it is the most often over-looked). This is the task of mobilizing political support. The mobilization of political support resonates most clearly when one thinks of the need to ensure that the providers and consumers of a new educational initiative embrace it with enthusiasm. Plans must be developed so that students and their families are aware of the objectives of a new initiative, that communities learn of benefits for the collectivity; programmes for teachers, educational administrators and their representatives must similarly be developed.. Since new initiatives usually mean some form of job re-definition, it is important that educators see this as beneficial and that those who object to the changes be isolated. Political mobilization may also be necessary to ensure that materials for school construction are available when needed, that needed institutional administrative adjustments are carried out, and, especially, that funding proposals are approved. One important strategy for mobilizing political support is that of involving groups affected by the new initiative in the planning process. This will pay dividends not only in the form of enhanced support, but, more likely, in terms of an improved policy design.

A significant amount of planning and even de facto policy formulation take place during actual implementation. This is the case because, during implementation, the following is the rule rather than the exception:

a) Circumstances related to implementation constraints cause poilcy modifications to take place;

b) Feedback obtained during implementation causes reassessment of aspects of the policy decision and subsequent modifications by policymakers; and

c) The mere translation of abstract policy intentions into concrete implementation causes reassessment and re-design. These changes occur with great frequency because, unfortunately, implementation problems are often greatly under-estimated during the stage of policy planning.

Misjudging ease of implementation is, perhaps, the most frequent error in policy planning. No matter how deeply the various groups affected by a new initiative have been involved in reviewing and shaping plans, the concreteness of the first day of a new programme, often casts it in a new light. Implementation is the time when one discovers that schedules are unrealistic and that programmes are over-ambitious; it is the time when the ravages of inflation cause the teachers' union to demand a pay increase prior to using the new texts; it is the time when parents conclude that the certification offered by the new programme may not guarantee their children the jobs they hoped for; and it is the time when local politicians decide that they should block the initiative since it will be so successful that it will prove that the politicians in the capital are better providers than they. Such problems are often replays of issues raised during the stages of evaluating policy options or of planning, and need to be solved by taking a flexible approach to the stage of policy implementation.

No matter how well anticipated, policy implementation always brings some surprises. These shape the policy output, sometimes in crucial ways. One way to use such surprises to improve policy outcomes is to design the implementation in stages. If unanticipated problems arise at a given stage, then a reevaluation of the plans for implementation, and possibly of the policy decision itself, is in order. Another way is to conduct well designed pilot studies, before full implementation of any projects. Problems of going to scale and the dangers of the 'greenhouse' projects that cannot survive implantation in the real world are well treated in Kemmerer (1990).

\subsection{Implications of Educational Planning for National Development}

Education is an instrument for excellence. It librates people from poverty and ignorance. Ukeje (1966) believes that "education is for life and for living. It is an investment in people which pays untold 
dividends to the society. When that investment is not made or is made inadequately, the society suffers a loss". Presumably it is in recognition of this importance of education that the 1999 constitution of the Federal Republic of Nigeria provided at Section 18 as follows:

(1) Government shall direct its policy towards ensuring that there are equal and adequate educational opportunities at all levels.

(2) Government shall promote science and technology.

(3) Government shall strive to eradicate illiteracy; and to this end, Government shall as and when practicable provide:

a) free, compulsory and universal primary education

b) free secondary education

c) free university education, and

d) free adult literacy programs (FRN, 2014).

It is in pursuance of this constitutional provision that the National Policy on Education was developed and accepted. Nigeria's educational philosophy is also anchored on this constitutional mandate. The importance of education to national development is no longer in doubt. The issue that agitates the mind is the effect of poor implementation of educational policies on the development of Nigeria. It was Ake (1988) in (Mba 2010) who said that "education is the process of becoming the best we can be". With the numerous crises in the educational system engendered by poor policy implementation, it is doubtful whether its recipients are really becoming the best as expected. If not, what is the fate of Nigeria?

The euphoria with which Nigerians welcomed the National Policy on Education has died down and been replaced with despondency due to non-performance. The National Educational Research Council Report of the Baguada Seminar of September 1980 captured this euphoria as expressed in that seminar thus: The introduction of the new system of education is deemed crucial to the implementation of the philosophy of "developmentalism". It is hoped that when fully operational, it will help transform the society and launch the nation along the developmental trajectory that will lead us to a state of parity with the advanced world (Baguada Report 1980). In the same state of mind, Ukeje (1986) noted that "the 6-3-3-4 system is more than a structure. It is a new process, a new orientation and a new activity, which hopefully will lead to new individuals and a new and bright future". The ineffective implementation of the various programs canvassed by the National Policy on Education has relegated these hopes and optimism to back-stage. Nigeria is caught between one 'evil' (the rejected British educational system which is still unofficially practised) and one 'saint' (the accepted American educational system which we can neither officially nor unofficially practise). Consequently, the conservatism of the British educational system which helped us to maintain our traditional values and a healthy society has been lost. On the other hand, the American system with its potential for technological development and growth has failed to make any difference in our society because we have not learned anything.

In the present circumstance, the dream of Nigeria to move to a state of parity with the advanced world appears to be a mirage. Ukeje (1986) was full of hope that the new system would lead to new individuals and a new and bright future. Eighteen years later, the system has not produced new individuals and the future appears more hopeless than in 1982 when the policy commenced. If Nigeria continues to hide under the umbrella of the National Policy on Education conscious of the implementation problems, our national aspirations will suffer greater impediments. Our national development will only rely on miracles, if any. The British system of education was found inadequate for Nigeria's developmental purposes. It is also true that the American system has failed in Nigeria because of our sociological circumstances. We need not continue to deceive ourselves with a national educational policy that has been found unworkable else in the future there will be no policy to lay hold on.

\section{SUGGESTIONS}

Premised on the limitations of educational planning identified and discussed, it is suggested that: 
- Educational planners should intensify effort to plan education to bridge the existing gaps at all levels of education in Nigeria. Education should be planned in such a way that interested citizens would have access to available educational opportunities. Educational planning should be carried out in such a way that it relates to the world of work, the demand for education and educational opportunities.

- The federal and state governments should be committed to the implementation of educational plans by adequately funding the education sector. Money is needed for the training of educational planners to acquire new skills and technology in educational planning. Similarly, administration of education requires money to enhance effectiveness. The government of Nigeria should continue to partner strongly with individuals and private organizations (NGOs) in the funding of education. Education is big business and needs a huge sum of money. Through the public-private partnership, educational services and opportunities can be sufficiently provided for the citizenry. Adeyemi and Oguntimehin (2000) suggest that the Nigerian government should promulgate a standing funding policy on education that will survive any regime in power, civilian or military. Although, education and politics are like Siamese twins, the federal government should look beyond this horizon and separate education from politics. This will help the educational planners and other experts to evolve an integrated system for national development. This will also enhance consistency in educational policy and check forceful termination of educational plans, policies and programmes by the government in power. Educational planners should take into account in the planning process changes and technological development, social and cultural needs and aspiration of the society. It is when these things are considered that effective educational planning can be ensured.

- Efforts should be made by planner to avoid poor forecasting in terms of over estimation and underestimation of educational resources such as human, material, financial and physical resources. Wrong projection of students/pupils enrolment should be reduced to the barest minimum. Certified educational planners should be charged with the responsibility of planning education for the country. The planning personnel in the planning units of the ministries of education should be experts in this area. They should be people who have the skills and knowledge of planning. Those who can collect needed data, collate, analyze and interpret them successfully and use them appropriately for educational planning. Periodic workshops conferences and seminars should be organized for them to update their knowledge and technical know-how. The government should ensure effective monitoring supervision and evaluation of plan implementation. This will help the government to know the extent of success or failure in plan implementation. Supervisory and evaluation reports help educational planners and the government to take remedial measures or to review the plan if necessary. In order to succeed here there is need for effective management of information system. There should be effective communication of information between planners and implementers of the plan. Educational planners in Nigeria should adopt strategic planning. This is a type of planning in which education stakeholders are given opportunities to contribute their ideas and knowledge to the development of the education plan. They contribute to the formulation of goals and objectives as well as education policies that will reflect the needs of the society.

- The entrenchment of education as a non-negotiable right of every citizen in the constitution would help check corruption in that sector. Corruption is largely responsible for the failure of the National Policy on Education and other policies in Nigeria.

- Mismanagement of educational resources at any level should be made a serious offence attracting a minimum of five years' imprisonment. This should be included in the next constitution of Nigeria. It is believed that in the presence of corruption no new system of education can succeed.

- Every effort should be made to eradicate corruption from all spheres of Nigeria's various programs so that available resources can be utilised for public interest.

\section{REFERENCES}

[1] Adepoju, T.L. (2000). Planning for an effective educational policy in Nigeria: A planner's view. In J.O. Fadipe and E.E. Oluchukwu (eds.) Educational Planning and Administration in Nigeria in the 21 st century. Pp (47-65), Ibadan: NIEPA.

[2] Adesina, O. (2004). The Guardian Newspaper, Monday, 1 November, p.16. 
[3] Adesina, S. (1977). Planning and educational development in Nigeria, Ibadan: Education Industries (Nigeria) Ltd.

[4] Adighije, C. (2005). Saturday Sun Newspaper, 9 April, p. 5.

[5] Aghenta, J.A. (1984). Towards a systems approach to the planning of secondary education in Nigeria', in Adesina, Segun and Ogusaju (eds.), Secondary education in Nigeria, Ile Ife: University of Ife Press.

[6] Akagbou, S.D. (1985). The economics of educational planning in Nigeria, India: Vikas Publishing House, PVT Ltd.

[7] Ake, C. (1988). 'Quality education in a dwindling economy', lecture delivered on the occasion of the 11th Convocation Ceremony of the Rivers State College of Education, Port Harcourt.

[8] Akpan, C. P. (2000). Effective planning: A pre-requisite for successful implementation of the Universal Basic Education (UBE) scheme. International Journal of Research in Basic and Life-Long Education. 1(1\&2), 102-109.

[9] Akpan, C. P. (2011). Fundamentals of School Business Management. Calabar: Primchoice Konsult.

[10] Akpan, C.P. (2000). Types of Educational Planning/Reasons for Planning Education. Dept. of Educational Administration and Planning University of Calabar, Calabar

[11] Awokoya, S.O. (1981). 'The parameters of educational planning', in Adesina, S. (ed.), Introduction to educational planning. Ile Ife: University of Ife Press.

[12] Baguada Report (1980). Perspectives of quantities and qualities in Nigerian education, NERC Report of the Baguada Seminar.

[13] Bello, J.Y. (1986). 'The 6-3-3-4 system: another exercise in futility?', a paper presented at the Annual Convention of the Nigeria Association of Educational Administration and Planning at the University of Port Harcourt.

[14] Ejiogu, B. (2005). Daily Sun Newspaper, Monday, 11 April, p.10. Federal Republic of Nigeria (1999). The Constitution of the Federal Republic of Nigeria, Abuja: Federal Ministry of Information.

[15] Federal Republic of Nigeria (2014). National policy on education. Lagos: NERDC.

[16] Hoy, W. \& Miskel, G.G. (2005). Educational administration: Theory, research and practice. New York: Random House.

[17] Kemmerer, F. (1990). Going to scale: Why successful instructional development projects fail to be adopted, in D. Chapman and C. Carrier (Eds.), improving educational quality: A global perspective. Westport, Connecticut: Greenwood Press, 243-256.

[18] Kerr, D.H. (1976). Educational policy: analysis, structure and justification, New York: David McKay Company.

[19] Klees, S.J. (1986). Planning and policy analysis in education: What can economists tell us? Comparative Education Review, 574-607.

[20] Obasanjo, O. (2005). The Guardian Newspaper, Wednesday, 23 March, p.11. Okeke, B.S. et al. (1985). A handbook on educational administration, Owerri: New African Publishing Co. Ltd.

[21] Okoroma, N.S. (2000). The perspectives of educational management, planning and policy analysis, Port Harcourt: Minson Publishers.

[22] Okoroma, N.S. (2001). 'An evaluation study of the 3-3 aspect of the National Policy on Education in Port Harcourt and Obio/Akpor Local Government areas of Rivers State', Journal of Technical and Science Education, vol. 10, nos. 1 \& 2.

[23] Okoroma, N.S. (2003). 'Factors militating against the effective implementation of the basic education programme in Rivers State', unpublished paper.

[24] Okoroma, N.S. (2006). Educational policies and problems of implementation in Nigeria. Rivers State University of Science and Technology Nigeria. Australian Journal of Adult Learning 46(2), 242-263.

[25] Okwori, A. (2011). Conceptual and Practical Approach to Educational Planning. Makurdi: Aboki publishers.

[26] Olufu, M. A. (2003). Introduction to the Fundamentals of Curriculum Development. Calabar: Ushie Printers and Publishers.

[27] Omolewa, M. A. (2006). Cross Over into the other side. The mission of Adult Education. A Valedictory lecture at the University of Ibadan. Ibadan.

[28] Osuji, F. (2005). Daily Sun Newspaper, Wednesday, 13 April, p. 1.

[29] Peerzada, N. (2016). Educational Ideas of Fridrich August Froebel. International Journal of Scientific Research and Education. 4(2). 4983-4988.

[30] Terry, G.R. (1977). Principles of management, Illinois: Richard D. Irwin, Inc.

[31] Ukeje, B.O. (1966). Education for social reconstruction, Lagos: Macmillan and Co. (Nig) Ltd.

International Journal of Humanities Social Sciences and Education (IJHSSE) Page | 141 
[32] Ukeje, B.O. (1986). School and society in Nigeria, Enugu: Fourth Dimension Publishing Co. Ltd.

[33] UNESCO (2003). Educational for All: The Leap to Equality. Paris: IIPE.

[34] Van Horn, C.E. \& Van Meter, D.S. (1977). 'The implementation of intergovernmental policy', Policy Studies Review, vol. 1, London: Stage Publications.

[35] Wikipedia (n.d). The Meaning of Education. Available online: http://en.wikipedia.org/wiki.education. Accessed on February, 2018.

Citation: Mba, Callistus Okechukwu Ph.D, Ugwulashi, Chima Sebastine Ph.D,. "Assessment of Educational Planning and Policy Implementation" International Journal of Humanities Social Sciences and Education (IJHSSE), vol 7, no. 4, 2020, pp. 129-142. doi: http://dx.doi.org/10.20431/2349-0381.0704013.

Copyright: (C) 2020 Authors. This is an open-access article distributed under the terms of the Creative Commons Attribution License, which permits unrestricted use, distribution, and reproduction in any medium, provided the original author and source are credited. 